\title{
Profil Cuaca dan Parameter Nisbah Bowen di Areal Persawahan Kabupaten Indramayu Saat Periode Kering Musim Tanam II
}

\author{
Roberto I. C. O. Taolin ${ }^{\text {a }}$, Impron ${ }^{\mathrm{b}}$, Rini Hidayati ${ }^{\mathrm{b}}$, dan Bregas Budianto ${ }^{\mathrm{b}}$
}

${ }^{a}$ Fakultas Pertanian, Universitas Timor, Kefamenanu, TTU - NTT, Indonesia.

${ }^{b}$ Departemen Geofisika dan Meteorologi, Institut Pertanian Bogor, Bogor, Indonesia.

\section{Article Info}

Article history:

Received 4 Oktober 2016

Received in revised form 20 November 2016 Accepted 9 Januari 2017

\section{Keywords:}

Profil Cuaca

Nisbah Bowen

Limpahan Bahang Laten

Limpahan Bahang Tanah

Gradien Suhu

Indramayu

\section{Abstrak}

Penelitian ini bertujuan untuk mendapatkan profil cuaca serta semua komponen yang mempengaruhi neraca energi selama periode kering musim tanam II yang terjadi di areal persawahan Kabupaten Indramayu, dilaksanakan bulan Juni hingga September 2012. Hasil penelitian menunjukkan fluktuasi cuaca harian dan parameter Nisbah Bowen umumnya mengikuti penerimaan radiasi neto sesuai karakter masingmasing seperti suhu, gradien suhu bola kering, kecepatan angin, limpahan bahang tanah dan limpahan bahang laten yang meningkat selama siang hari dan menurun kembali menjelang sore hari. Sebaliknya, gradien suhu bola basah, kelembaban dan tekanan udara, menurun selama siang hari dan kembali meningkat menjelang sore hari. Rata-rata harian unsur cuaca dan parameter bowen antara lain radiasi neto $241 \mathrm{~W}$ $\mathrm{m}^{-2}$, suhu udara $28,3{ }^{\circ} \mathrm{C}$, kelembaban relatif $66 \%$, tekanan udara $101 \mathrm{kPa}$, limpahan bahang tanah $8,1 \mathrm{~W} \mathrm{~m}^{-2}$, nisbah bowen 0,16 , limpahan bahang laten $172,9 \mathrm{~W} \mathrm{~m}^{-2}$. Radiasi neto yang diterima permukaan selama penelitian relatif konstan antara $183 \mathrm{~W} \mathrm{~m}^{-2}$ sampai $268 \mathrm{~W} \mathrm{~m}^{-2}$ dengan rata-rata $231 \mathrm{~W} \mathrm{~m}^{-2}$, suhu udara rata-rata $29,4{ }^{\circ} \mathrm{C}$. Kelembaban relatif berkisar antara $45 \%$ hingga $67 \%$ dengan rata-rata $59 \%$, sedangkan tekanan udara rata-rata $101 \mathrm{kPa}$. Angin bertiup lebih banyak ke arah tenggara $\left(138,4^{\circ}\right)$ dengan kecepatan rata-rata $0,9 \mathrm{~m} \mathrm{~s}^{-1}$.

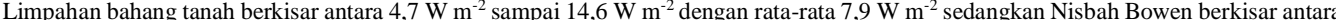
0,02 sampai 0,22 dengan rata-rata 0.10 . Limpahan bahang laten berbanding lurus terhadap penerimaan radiasi neto dengan nilai berkisar antara $134,4 \mathrm{~W} \mathrm{~m}^{-2}$ sampai $226,5 \mathrm{~W} \mathrm{~m}^{-2}$ dengan rata-rata $184 \mathrm{~W} \mathrm{~m}^{-2}$. $\odot 2017$ dipublikasikan oleh Savana Cendana.

\section{Pendahuluan}

Lahan sawah di pantai utara Jawa Barat berperan besar bagi suplai/pasokan beras nasional. Permasalahan keterbatasan sumberdaya air sering menjadi fakto pembatas produksi akibat kekeringan, terutama pada akhir musim tanam kedua/gadu yang terjadi hampir setiap tahun. Evapotranspirasi merupakan salah satu proses yang menyebabkan lahan persawahan mengalami kehilangan air Wang et al. (2012) mendefinisikan evapotranspirasi sebagai perubahan wujud dari $\mathrm{H}_{2} \mathrm{O}$ cair menjadi uap atau gas serta bergerak dari bidang penguap (permukaan tanah dan vegetasi) ke atmosfir.

Besarnya evapotranspirasi dipengaruhi oleh tiga aspek yaitu keadaan iklim, karakteristik tanaman serta pengelolaan dan kondisi lingkungan berupa kerapatan tanaman, kondisi tanah, ketersediaan dan distribusi air. Aspek iklim yang mempengaruhi nilai evapotranspirasi adalah radiasi matahari, suhu, kelembaban udara dan kecepatan angin (Allen et al. 1998).

Karakteristik permukaan juga mempengaruhi evapotranspirasi sepert tahanan aerodinamik, tahanan permukaan dan albedo (Allen et al. 1998) Tahanan aerodinamik $\left(\mathrm{r}_{\mathrm{a}}\right)$ merupakan perpindahan panas dan uap air dari permukaan tanah, sedangkan tahanan permukaan $\left(\mathrm{r}_{\mathrm{s}}\right)$ merupakan tahanan dar aliran uap air melalui transpirasi tanaman dan evaporasi permukaan tanah. Ketika vegetasi tidak seluruhnya menutupi tanah, faktor tahanan sangat dibutuhkan karena sangat berpengaruh terhadap evaporasi permukaan tanah. Jika transpiras tidak optimal maka tahanan permukaan akan dipengaruhi oleh ketersediaan ai di permukaan. Tahanan stomata dipengaruhi oleh kondisi iklim dan ketersediaan air. Namun, jenis tanaman lebih mempengaruhi nilai tahanan stomata.

Pendugaan nilai evapotranspirasi antara lain dapat dilakukan dengan menggunakan metode Nisbah Bowen. Beberapa peneliti di berbagai negara telah membuktikan kehandalan metode Nisbah Bowen, terutama menyangkut proses proses fisik (pemindahan energi) di atas permukaan tajuk yang sulit dijelaskan melalui metode lain dalam kaitannya dengan evapotranspirasi. Pengukuran dengan metode Nisbah Bowen dapat dilakukan langsung di lapangan (in situ) tanpa gangguan fisik terhadap lahan dan hasil pendugaan dapat menghitung laju evapotranspirasi dalam periode pendek, misalnya per jam atau tiap setengah jam (Grant, 1975).

Laju evapotranspirasi dari suatu pertanaman sangat tergantung pada ketersediaan energi, defisit tekanan uap, kecepatan angin dan suhu udara, sedangkan faktor vegetasi yang berpengaruh adalah hantaran stomata/tajuk dan struktur karakteristik tajuk yang berpengaruh pada hantaran aerodinamik (Jarvis dan Stewart 1979). Evaporasi dari suatu permukaan dapat ditentukan dengan baik jika semua komponen yang mempengaruhi neraca energi di permukaan yang bersangkutan diketahui, yaitu radiasi neto $\left(R_{n}\right)$, fluks bahang terasa $(H)$ dan fluks bahang tanah $(\mathrm{G})$. $\mathrm{R}_{\mathrm{n}}$ dan $\mathrm{G}$ yang dapat diukur secara langsung dan mudah. $\mathrm{H}$ dan LE dapat dihitung dengan menggunakan metode Nisbah Bowen (Rosenberg et al. 1983).

Penelitian ini bertujuan untuk mendapatkan profil cuaca serta semua komponen yang mempengaruhi neraca energi selama periode kering musim tanam II yang terjadi di areal persawahan Kabupaten Indramayu.

\section{Metode}

Penelitian dilaksanakan pada bulan Juni hingga September 2012. Perakitan alat Nisbah Bowen dilakukan di Laboratorium Instrumentasi Meteorolog Departemen Geofisika dan Meteorologi, FMIPA, Institut Pertanian Bogor Percobaan lapang dilaksanakan di persawahan yang terletak di Desa Langgengsari, Kecamatan Lelea, Kabupaten Indramayu, Provinsi Jawa Barat Bahan yang digunakan dalam penelitian ini adalah pipa PVC ukuran 1 inci (AW 1"), sambungan pipa, perekat pipa PVC, alumunium foil, benang, kawat solder, kawat tembaga, kawat konstantan dan selang pelindung kawat/kabel. Alat yang digunakan dalam penelitian ini adalah Middleton CN1 Net Pyrradiometer
S/No.1108, termokopel type T (Copper/Constantan), pengganda tegangan (OpAmp), Automatic Weather Station (AWS), data logger type GL500, digita multimeter type DT-830B, solder listrik, thermometer air raksa, keping sensor fluks panas (Soil Heat Flux Plate), botol berukuran $10 \mathrm{ml}$, kipas penyedot udara dan aki 6 volt model Panasonic LC-R064R5P.

Perakitan alat Nisbah Bowen meliputi pembuatan termokopel tipe T, pembuatan pengganda tegangan (amplifier) dan pembuatan tiang penyangga. Termokopel (sensitifitas $43 \mu \mathrm{V}{ }^{\circ} \mathrm{C}^{-1}$ ) dibuat dengan cara menghubungkan tembaga sebagai konduktor positif dan konstantan sebagai konduktor negatif. Jumlah termokopel yang dibuat adalah 12 buah dan setiap tiga buah termokopel dihubungkan secara seri sehingga terdapat 4 paket termokopel yang setiap kawat konduktornya dilindungi dengan selang pelindung kawat/kabel. Pada titik-titik sambungan pada dua paket termokopel diberikan lilitan benang untuk kepentingan pengukuran gradien suhu bola basah. Rangkaian termokopel dapat dilihat pada Gambar 1.
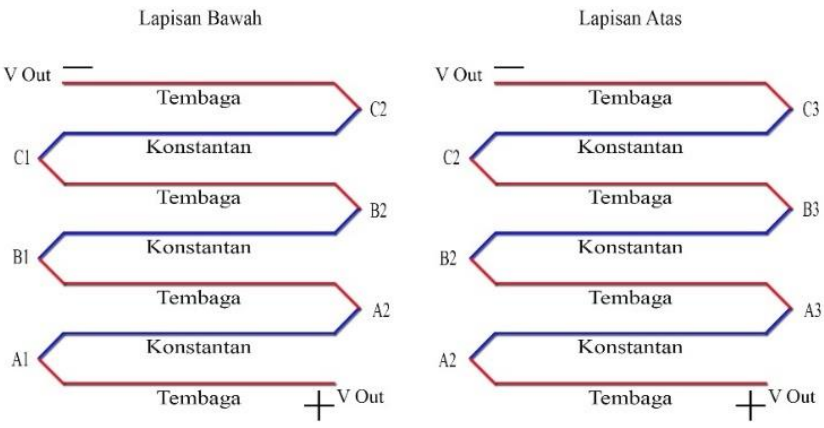

Gambar 1 Rangkaian termokopel

Pengganda tegangan (Op-Amp) merupakan rangkaian elektronik yang berfungsi untuk mengolah arus listrik termokopel yang berupa tegangan yan kecil menjadi tegangan yang lebih besar, sehingga output dari rangkaian ini dapat dibaca oleh multimeter. Pengganda tegangan yang dibuat memberikan penguatan 250 kali sehingga output pengganda tegangan ini memiliki karakteristik yang linear dengan sensitifitas $11 \mathrm{mv}^{\circ} \mathrm{C}^{-1}$.

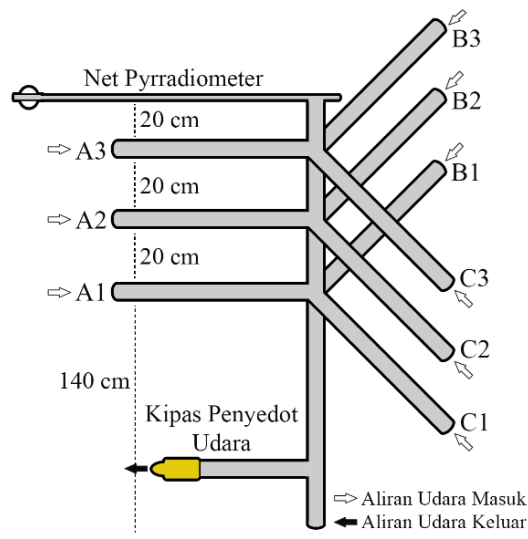

Gambar 2 Rancangan sistim Nisbah Bowen 
Tiang penyangga dibuat dengan bahan dasar pipa PVC berukuran 1 inci dengan tinggi $200 \mathrm{~cm}$. Bagian ujung atas disediakan tempat untuk pemasangan net pyrradiometer. Pada ketinggian $140 \mathrm{~cm}, 160 \mathrm{~cm}$ dan $180 \mathrm{~cm}$ disiapkan tempat pemasangan 4 paket psikrometer elektronik yang menjorok secara horizontal sepanjang $40 \mathrm{~cm}$ pada tiga arah yang berbeda membentuk sudut $120^{\circ}$ seperti pada Gambar 2.

Termokopel dipasang melalui bagian dalam pipa dan menempatkan sensor di bagian ujung-ujung pipa yang menjorok (A1 - C 3). Ujung benang yang terlilit pada termokopel direndam dalam botol penampungan yang berisi air sehingga menghasilkan aliran kapiler untuk pembasahan sensor. Pada ujung bawah penyangga dipasang kipas penyedot udara yang dihubungkan dengan aki.

Alat yang dipasang di areal percobaan meliputi sistem Nisbah Bowen, sepasang termometer air raksa (bola kering dan bola basah) dan Automatic Weather Station (AWS). Sistem Nisbah Bowen ditempatkan di areal persawahan dengan memperhatikan lebar fetch yakni lebih dari 100 kali ketinggian sensor. Keping sensor limpahan bahang tanah dipasang di bawah sistem Nisbah Bowen dengan kedalaman $20 \mathrm{~cm}$ dari permukaan tanah. Sepasang termometer air raksa ditempatkan pada tiang penyangga berbeda dengan ketinggian $2 \mathrm{~m}$ dari permukaan tanah.

Komponen cuaca yang diukur dengan sistem Nisbah Bowen adalah radiasi neto, suhu bola basah dan bola kering, gradien suhu bola basah dan bola kering pada ketinggian antara $140 \mathrm{~cm}$ dan $160 \mathrm{~cm}$ serta pada ketinggian antara $160 \mathrm{~cm}$ dan $180 \mathrm{~cm}$ dan limpahan bahang tanah. Pengukuran setiap 30 menit mulai pukul 06.00 sampai pukul 18.00 dilakukan dengan cara menghubungkan multimeter pada pengganda tegangan kemudian dilakukan pembacaan nilai offset dan selanjutnya dihubungkan pada masing-masing sensor, sedangkan untuk net pyrradiometer dan keping sensor limpahan bahang dilakukan dengan cara langsung dihubungkan dengan multimeter. Komponen yang diukur dengan AWS adalah radiasi $\left(\mathrm{W} \mathrm{m}^{-2}\right)$, suhu $\left({ }^{\circ} \mathrm{C}\right)$, kelembaban $(\%)$, tekanan udara (mBar), curah hujan $(\mathrm{mm})$, arah angin $\left({ }^{\circ}\right)$ dan kecepatan angin $\left(\mathrm{km} \mathrm{jam}^{-1}\right)$. Pencatatan data dilakukan setiap 30 menit menggunakan data logger type GL500.

\section{Hasil dan Pembahasan}

\subsection{Radiasi Neto}

Radiasi neto $\left(\mathrm{R}_{\mathrm{n}}\right)$ merupakan selisih antara gelombang pendek dan gelombang panjang yang datang ke permukaan dengan gelombang pendek dan gelombang panjang yang hilang dari permukaan. $\mathrm{R}_{\mathrm{n}}$ yang diterima permukaan selama penelitian relatif konstan antara $182 \mathrm{~W} \mathrm{~m}^{-2}$ sampai $268 \mathrm{~W} \mathrm{~m}^{-2}$ dengan rata-rata harian $231+18 \mathrm{~W} \mathrm{~m}^{-2}$

$R_{n}$ tertinggi terjadi pada tanggal 18 Agustus sedangkan $R_{n}$ terendah yang diterima permukaan terjadi pada tanggal 9 September. $R_{n}$ meningkat sejak pagi hari sejalan dengan terbitnya matahari hingga mencapai puncak radiasi pada pukul 12.00 sebesar $449 \mathrm{~W} \mathrm{~m}^{-2}$ kemudian menurun hingga mencapai radiasi minimum sebesar $-35 \mathrm{~W} \mathrm{~m}^{-2}$ pada pukul 18.00 . Secara umum pola radiasi neto berupa fluktuasi setiap 30 menit, sebaran data dan standar deviasi, fluktuasi harian selama periode pengamatan dan variasi diurnal tanggal 17 Agustus 2012 seperti ditunjukkan pada Gambar 3.
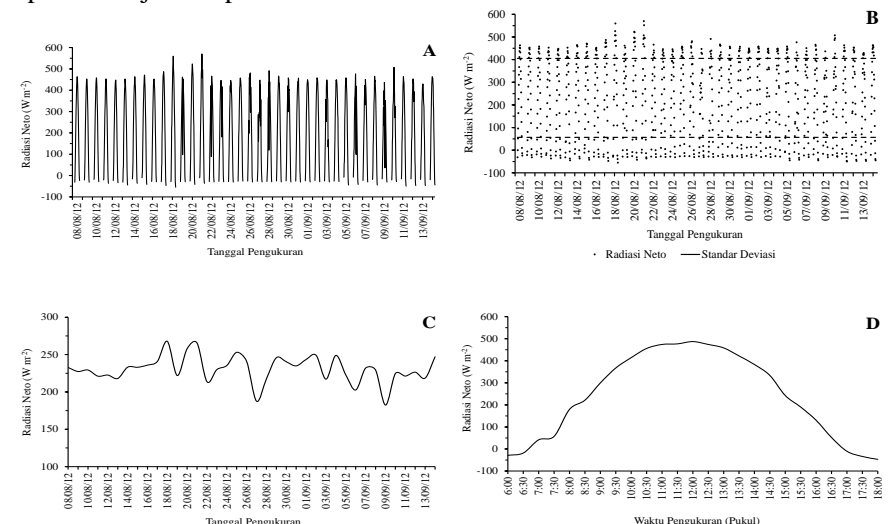

Gambar 3 Pola radiasi neto $\left(\mathrm{R}_{\mathrm{n}}\right)$. Fluktuasi setiap 30 menit $(A)$, sebaran data dan standa deviasi (B), fluktuasi harian (C) selama periode pengamatan, variasi diurnal tanggal 17 Agustus 2012 (D)

\subsection{Suhu Udara}

Suhu udara berfluktuasi dengan nyata selama setiap periode 24 jam, fluktuasi suhu udara berkaitan erat dengan proses pertukaran energi yang berlangsung di atmosfer. Sebagian dari radiasi matahari akan diserap oleh gasgas atmosfer dan partikel-partikel padat yang melayang di atmosfer pada siang hari. Serapan energi radiasi matahari ini menyebabkan suhu udara meningkat.

Suhu udara (bola kering) selama pengukuran pukul $06.00-18.00$ menunjukkan selang yang cukup besar, yakni $20,5^{\circ} \mathrm{C}$ sampai $31,5^{\circ} \mathrm{C}$, sedangkan rata-rata suhu harian bervariasi antara $28,2{ }^{\circ} \mathrm{C}$ sampai $31,2{ }^{\circ} \mathrm{C}$ dengan rata-rata $29,4+0,81{ }^{\circ} \mathrm{C}$. Suhu bola basah selama pengukuran (pukul $06.00-18.00$ ) memiliki selang yang lebih kecil, yakni $18,2^{\circ} \mathrm{C}$ sampai $25,2^{\circ} \mathrm{C}$. Suhu maksimum selama penelitian berkisar antara $31,5^{\circ} \mathrm{C}$ sampai $35,5^{\circ} \mathrm{C}$, sedangkan suhu minimum berkisar antara $20^{\circ} \mathrm{C}$ sampai $25^{\circ} \mathrm{C}$. Pola suhu udara dapat di lihat pada Gambar 4.
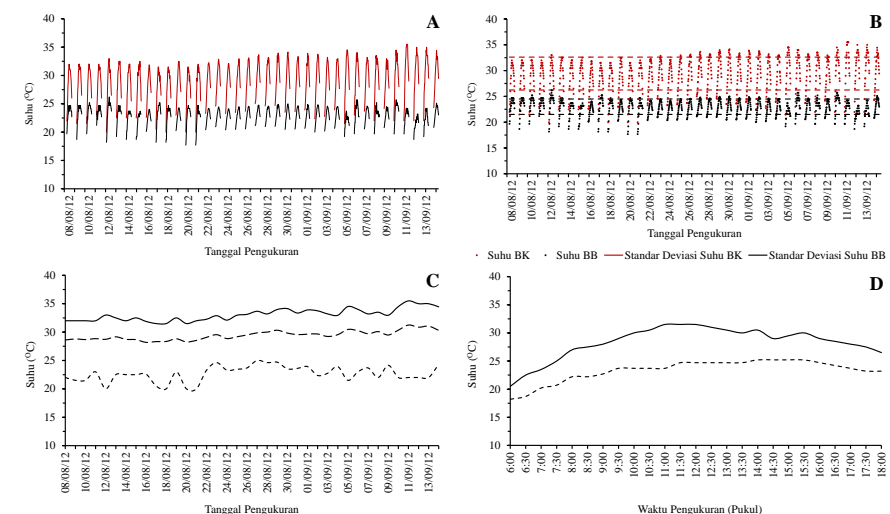

Gambar 4 Pola suhu udara. Fluktuasi suhu bola kering (merah) dan bola basah (hitam) setiap 30 menit (A), sebaran data dan standar deviasi (B), fluktuasi, harian - suhu maksimum, ----- suhu rata-rata, …… suhu minimum (C) selama periode pengamatan dan variasi diurnal, — suhu bola kering, …... bola basah tanggal 17 Agustus 2012 (D)

\subsection{Kelembaban dan Tekanan Udara}

Hasil pengukuran selama penelitian menunjukkan adanya variasi kelembaban relatif $(\mathrm{RH})$ antara $45 \%$ hingga $67 \%$ dengan rata-rata $59+5 \%$, ratarata tekanan udara $101+0,1 \mathrm{kPa}$. Fluktuasi harian $\mathrm{RH}$ berkisar antara $52 \%$ sampai $80 \%$ dengan rata-rata $66 \%$.
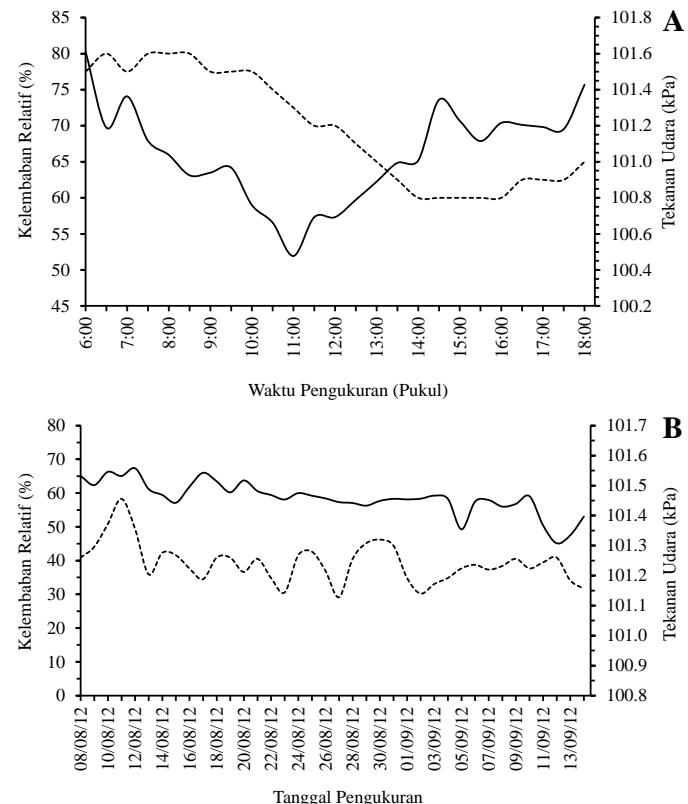

Gambar 5 Pola kelembaban udara (-) dan tekanan udara (……). Variasi diurnal tanggal 17 Agustus 2012 (A) dan fluktuasi harian selama periode pengamatan (B)

RH umumnya relatif tinggi pada pagi hari kemudian menurun hingga pukul 13.30, selanjutnya kembali meningkat hingga sore hari. Fluktuasi RH selalu diikuti oleh fluktuasi $\mathrm{P}$ beberapa saat kemudian yang bervariasi antara $101 \mathrm{kPa}$ sampai $102 \mathrm{kPa}$. Fluktuasi RH dan $\mathrm{P}$ dipengaruhi oleh T dimana RH berbanding lurus dengan $\mathrm{P}$ dan keduanya berbanding terbalik dengan T. Peningkatan $\mathrm{T}$ menyebabkan peningkatan kapasitas udara menampung uap air $\left(\mathrm{e}_{\mathrm{s}}\right)$ maka jika kandungan uap air di udara $\left(\mathrm{e}_{\mathrm{a}}\right)$ tetap maka $\mathrm{RH}$ akan menurun, demikian juga sebaliknya jika $\mathrm{T}$ menurun maka $\mathrm{e}_{\mathrm{s}}$ juga menurun dan menyebabkan $\mathrm{RH}$ meningkat jika $\mathrm{e}_{\mathrm{a}}$ tetap.

Peningkatan suhu menyebabkan udara memuai sehingga kerapatan udara berkurang dan menurunkan berat udara dan penurunan berat udara menyebabkan $\mathrm{P}$ juga menurun, sebaliknya jika $\mathrm{T}$ menurun maka kerapatan udara juga meningkat dan berat udara menjadi bertambah sehingga $P$ juga meningkat.

\subsection{Arah dan Kecepatan Angin}

Selama penelitian angin bertiup ke arah yang bervariasi antara $87,8^{\circ}$ (Timur) hingga $200,6^{\circ}$ (Selatan), dengan rata-rata tiupan angin menuju ke arah $138,4^{\circ}$ (Tenggara). Kecepatan angin juga bervariasi selama penelitian antara $0,5 \mathrm{~m} \mathrm{~s}^{-1}$ sampai $1,4 \mathrm{~m} \mathrm{~s}^{-1}$ dengan kecepatan rata-rata $0,9 \mathrm{~m} \mathrm{~s}^{-1}$. Fluktuasi harian kecepatan angin berkisar antara $0,0 \mathrm{~m} \mathrm{~s}^{-1}$ sampai $2,9 \mathrm{~m} \mathrm{~s}^{-1}$ dengan rata-rata $0.7 \mathrm{~m} \mathrm{~s}^{-1}$. Kecepatan angin umumnya relatif rendah pada pukul 06.00 menjelang matahari terbit, kemudian meningkat drastis hingga pukul 08.00, selanjutnya berfluktuasi pada siang hari dan kemudian menurun secara drastis pada sore hari setelah pukul 16.00 .

Pengaruh angin terhadap evapotranspirasi adalah melalui mekanisme pemindahan uap air yang keluar dari pori-pori daun. Semakin besar kecepatan angin, semakin besar pula laju evapotranspirasi yang dapat terjadi. Angin yang 
terjadi di lokasi penelitian diperkirakan akibat perbedaan tekanan udara antara permukaan laut dan daratan.

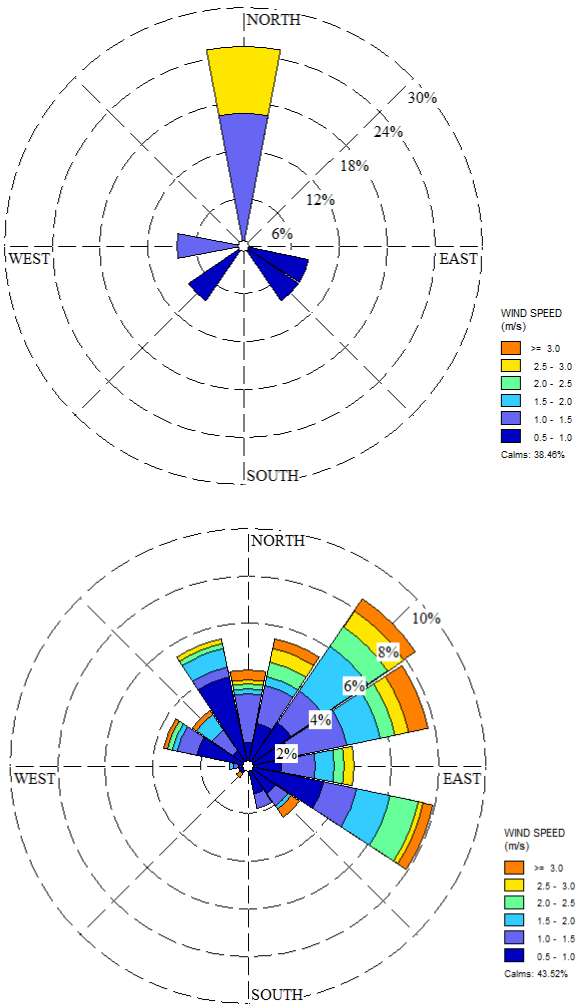

Gambar 6 Wind Rose tanggal 17 Agustus 2012 (atas), Wind Rose selama periode pengamatan (bawah)

\subsection{Gradien Suhu dan Nisbah Bowen}

Gradien suhu pada lapisan atas lebih besar dibandingkan pada lapisan bawah, baik gradien suhu bola kering maupun gradien suhu bola basah. Pada lapisan atas gradien suhu bola kering sejak pukul 06.00 sampai pukul 18.00 berkisar antara $0,0^{\circ} \mathrm{C} \mathrm{m}^{-1}$ sampai $0,9^{\circ} \mathrm{C} \mathrm{m}^{-1}$ dengan rata-rata $0,6^{\circ} \mathrm{C} \mathrm{m}^{-1}$. Gradien suhu bola basah berkisar antara $0,0{ }^{\circ} \mathrm{C} \mathrm{m}^{-1}$ sampai $0,6{ }^{\circ} \mathrm{C} \mathrm{m}^{-1}$ dengan rata-rata $0,3{ }^{\circ} \mathrm{C} \mathrm{m}^{-1}$. Pada lapisan bawah gradien suhu bola kering berkisar antara $0,0^{\circ} \mathrm{C}$ $\mathrm{m}^{-1}$ sampai $0,9^{\circ} \mathrm{C} \mathrm{m}^{-1}$ dengan rata-rata $0,4^{\circ} \mathrm{C} \mathrm{m}^{-1}$, sedangkan gradien suhu bola basah berkisar antara $0,0{ }^{\circ} \mathrm{C} \mathrm{m}^{-1}$ sampai $0,6{ }^{\circ} \mathrm{C} \mathrm{m}^{-1}$ dengan rata-rata $0,2{ }^{\circ} \mathrm{C} \mathrm{m}^{-1}$. Gradien suhu bola kering lebih rendah dibandingkan gradien suhu bola basah pada pagi dan sore hari, sedangkan pada siang hari gradien suhu bola kering lebih tinggi dibandingkan gradien suhu bola basah. Variasi diurnal gradien suhu bola kering dan gradien suhu bola basah pukul $06.00-18.00$ pada lapisan atas dan lapisan bawah dapat dilihat pada Gambar 7.

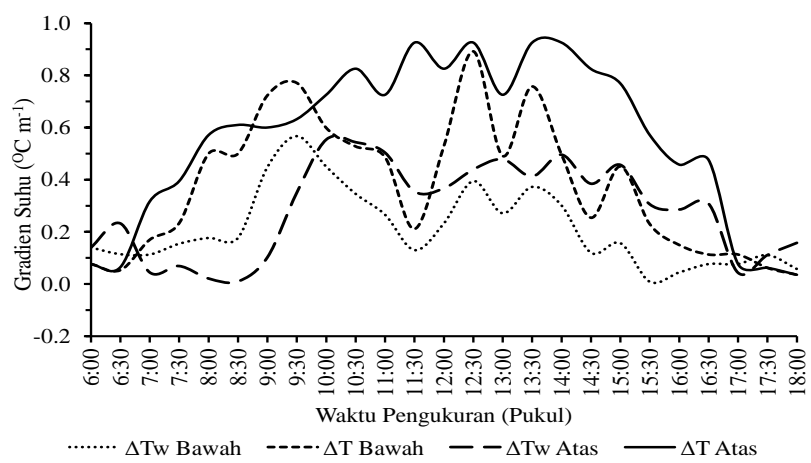

Gambar 7 Variasi diurnal gradien suhu bola kering dan gradien suhu bola basah tanggal 17 Agustus 2012

Nisbah Bowen selama periode pengukuran bervariasi dari hari ke hari antara 0,02 sampai 0,22 dengan rata-rata $0,10+0,06$. Nilai rata-rata $\beta$ yang diperoleh selama penelitian mendekati nilai rata-rata $\beta$ yang diperoleh Tsai et al. (2007) pada lahan sawah Taichung, Taiwan sebesar 0,18 tetapi relatif kecil jika dibandingkan dengan nilai $\beta$ yang diperoleh Gao et al. (2003) pada lahan sawah Anhui, China yakni sebesar 0,23 . Nilai $\beta$ yang relatif kecil menunjukkan bahwa proporsi energi yang digunakan untuk menguapkan air lebih besar dibandingkan dengan energi yang digunakan untuk pemanasan udara. Fluktuasi harian $\beta$ sejak pukul 06.00 sampai pukul 18.00 berkisar antara $-0,76$ sampai 0,65 (Gambar 8D). Nilai $\beta$ umumnya relatif kecil pada pukul 06.00 menjelang matahari terbit, kemudian meningkat drastis hingga pukul 07.00 sejalan dengan penerimaan radiasi surya, kemudian berfluktuasi pada siang hari dan menurun secara drastis pula pada sore hari menjelang matahari terbenam. Hal tersebut menunjukkan bahwa saat pagi hari setelah matahari terbit banyak proporsi energi yang digunakan untuk pemanasan udara, sehingga terjadi peningkatan suhu udara.
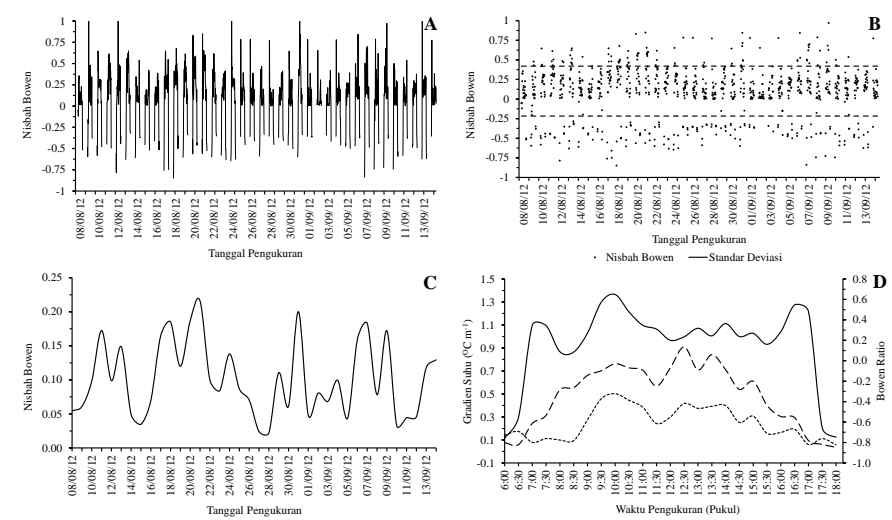

Gambar 8 Pola Nisbah Bowen. Fluktuasi setiap 30 menit (A), sebaran data dan standar deviasi (B), fluktuasi harian (C) selama periode pengamatan dan variasi diurnal ---- gradien suhu bola kering, …. gradien suhu bola basah dan — Nisbah Bowen tanggal 17 Agustus 2012 (D)

\subsection{Limpahan Bahang Tanah}

Hasil perhitungan $\mathrm{G}$ selama penelitian menunjukkan variasi rata-rata harian antara $4,7 \mathrm{~W} \mathrm{~m}^{-2}$ sampai $14,6 \mathrm{~W} \mathrm{~m}^{-2}$ dengan rata-rata $7,9+2,4 \mathrm{~W} \mathrm{~m}^{-2}$. Hingga pag hari pukul 06.00, limpahan bahang tanah masih negatif sebesar $-10,3 \mathrm{~W} \mathrm{~m}^{-2}$, kemudian meningkat hingga mencapai nilai maksimum beberapa saat setelah puncak radiasi surya yakni pada pukul 13.30 sebesar $19,3 \mathrm{~W} \mathrm{~m}^{-2}$, kemudian menurun hingga sore hari.

Gambar 9. menunjukkan fluktuasi nilai G, semakin besar pada akhir penelitian, hal ini disebabkan karena pada saat akhir penelitian telah memasuki musim kemarau dan masa panen sehingga tajuk tanaman padi mulai renggang dan radiasi surya yang mencapai permukaan tanah semakin meningkat dan radiasi bumi leluasa terlepas pada malam hari. Tsai et al. (2007) dalam penelitiannya juga menemukan bahwa $\mathrm{G}$ pada persawahan nilainya berkurang seiring dengan pertambahan umur tanaman padi sawah dan meningkat kembali pada saat menjelang panen. Selain itu, keadaan kandungan air tanah yang semakin kering juga menyebabkan nilai $\mathrm{G}$ semakin besar hingga akhir penelitian.
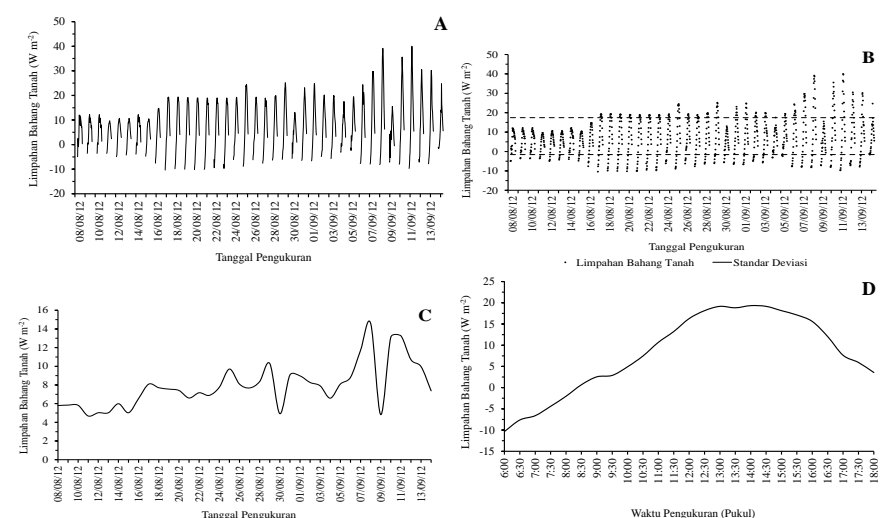

Gambar 9 Pola limpahan bahang tanah. Fluktuasi setiap 30 menit (A), sebaran data dan standar deviasi (B), fluktuasi harian (C) selama periode pengamatan dan variasi diurnal tanggal 17 Agustus 2012 (D)

\subsection{Limpahan Bahang Laten}

Hasil perhitungan LE selama penelitian menunjukkan variasi rata-rata harian antara $134,4 \mathrm{~W} \mathrm{~m}^{-2}$ sampai $226,5 \mathrm{~W} \mathrm{~m}^{-2}$ dengan rata-rata $184+21,5 \mathrm{~W} \mathrm{~m}^{-2}$. Nilai hariannya meningkat sejak pagi hari hingga mencapai puncak pada pukul 12.00 sebesar 392,3 $\mathrm{W} \mathrm{m}^{-2}$ kemudian menurun hingga mencapai nilai minimum sebesar $-85,3 \mathrm{~W} \mathrm{~m}^{-2}$ pada pukul 18.00 .

Gambar 11. menunjukkan selisih antara radiasi neto dan limpahan bahang laten semakin besar yang artinya proporsi energi yang digunakan untuk menguapkan air semakin kecil dari awal hingga akhir periode pengukuran. Hal ini berkaitan dengan ketersediaan air yang semakin berkurang untuk proses evapotranspirasi. Sebaliknya bahang terasa cenderung semakin meningkat sehingga menyebabkan suhu udara juga memiliki pola yang semakin meningkat.

Pada tanggal 8 Agustus 2012, hanya 2,5\% masukan energi yang digunakan sebagai limpahan bahang tanah dan sejumlah $9,9 \%$ yang digunakan untuk pemanasan udara sedangkan sisanya sebesar $87,6 \%$ digunakan sebagai limpahan bahang laten. Pada tanggal 21 Agustus 2012, hanya 2,5\% masukan energi yang digunakan sebagai limpahan bahang tanah dan masukan energi yang digunakan untuk pemanasan udara meningkat menjadi $29,9 \%$ sedangkan sisanya sebesar $67,6 \%$ digunakan sebagai limpahan bahang laten. Pada tanggal 7 September 2012, masukan energi yang digunakan sebagai limpahan bahang tanah meningkat menjadi $5 \%$ dan sejumlah $23,9 \%$ yang digunakan untuk pemanasan 
udara sedangkan sisanya sebesar 71,0\% digunakan sebagai limpahan bahang laten.
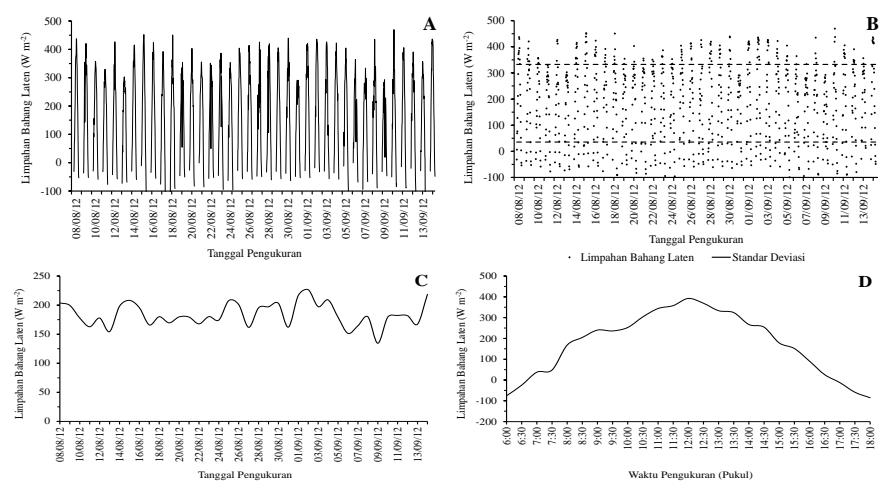

Gambar 10 Pola limpahan bahang laten. Fluktuasi setiap 30 menit (A), sebaran data dan standar deviasi (B), fluktuasi harian (C) selama periode pengamatan dan variasi diurnal tanggal 17 Agustus 2012 (D)

Secara umum, selama penelitian rata-rata $97,3 \%$ dari $\mathrm{Rn}$ yang diterima permukaan sawah digunakan untuk menguapkan air ke atmosfir dan LE memiliki nilai yang berbanding lurus terhadap penerimaan radiasi neto yang mengenai kawasan persawahan tersebut. Perbandingan Rn, LE, H dan G pada pukul 06.00 sampai pukul 18.00 dapat dilihat pada Gambar 11 .

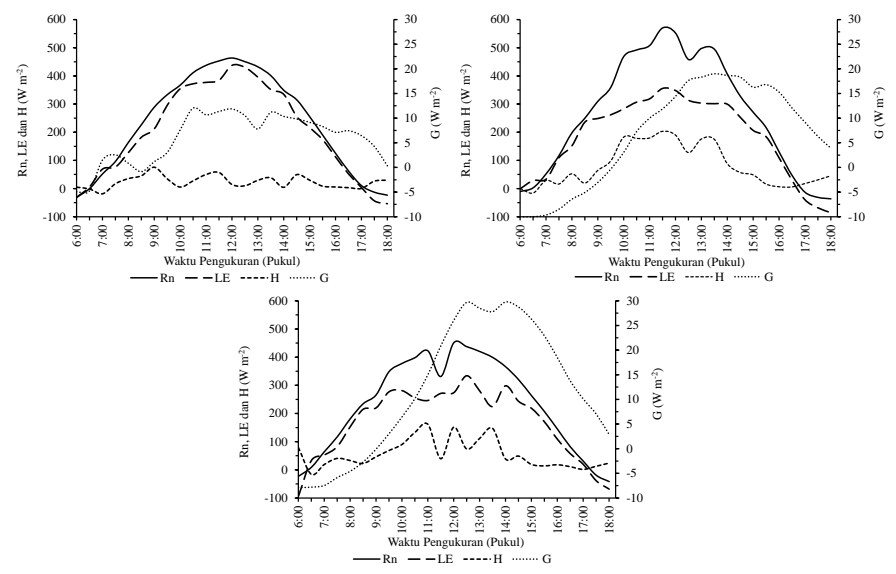

Gambar 11 Variasi diurnal radiasi neto (Rn), limpahan bahang laten (LE) dan limpahan bahang tanah (G) tanggal 8 Agustus 2012 (atas kiri), 21 Agustus 2012 (atas kanan) dan 7 September 2012 (bawah)

\section{Simpulan}

Fluktuasi cuaca harian dan parameter Nisbah Bowen umumnya mengikuti penerimaan radiasi neto sesuai karakter masing-masing seperti suhu, gradien suhu bola kering, kecepatan angin, limpahan bahang tanah dan limpahan bahang laten yang meningkat selama siang hari dan menurun kembali menjelang sore hari. Sebaliknya, gradien suhu bola basah, kelembaban dan tekanan udara, menurun selama siang hari dan kembali meningkat menjelang sore hari. Variasi diurnal radiasi neto berkisar antara $-47 \mathrm{~W} \mathrm{~m}^{-2}$ sampai $487 \mathrm{~W} \mathrm{~m}^{-2}$ dengan rata-rata $241 \mathrm{~W} \mathrm{~m}^{-2}$, suhu udara rata-rata $28,3{ }^{\circ} \mathrm{C}$ dengan suhu tertinggi $31,5^{\circ} \mathrm{C}$ dan suhu terendah $20,5^{\circ} \mathrm{C}$. Kelembaban relatif berkisar antara $52 \%$ hingga $80 \%$ dengan rata-rata $66 \%$, sedangkan tekanan udara rata-rata $101 \mathrm{kPa}$. Limpahan bahang tanah berkisar antara antara $-10,3 \mathrm{~W} \mathrm{~m}^{-2}$ sampai $19,3 \mathrm{~W} \mathrm{~m}^{-2}$ dengan rata-rata 8,1 $\mathrm{W} \mathrm{m}^{-2}$ sedangkan Nisbah Bowen berkisar antara $-0,76$ sampai 0,65 dengan ratarata 0,16 . Limpahan bahang laten berkisar antara $-85,3 \mathrm{~W} \mathrm{~m}^{-2}$ sampai $392,3 \mathrm{~W}$ $\mathrm{m}^{-2}$ dengan rata-rata $172,9 \mathrm{~W} \mathrm{~m}^{-2}$.

Rata-rata harian radiasi neto yang diterima permukaan selama penelitian relatif konstan antara $183 \mathrm{~W} \mathrm{~m}^{-2}$ sampai $268 \mathrm{~W} \mathrm{~m}^{-2}$ dengan rata-rata $231 \mathrm{~W} \mathrm{~m}^{-2}$, suhu udara rata-rata $29,4^{\circ} \mathrm{C}$ dengan suhu maksimum $35,5^{\circ} \mathrm{C}$ dan suhu minimum $20{ }^{\circ} \mathrm{C}$. Kelembaban relatif berkisar antara $45 \%$ hingga $67 \%$ dengan rata-rata $59 \%$, sedangkan tekanan udara rata-rata $101 \mathrm{kPa}$. Angin bertiup lebih banyak ke arah tenggara $\left(138,4^{\circ}\right)$ dengan kecepatan rata-rata $0,9 \mathrm{~m} \mathrm{~s}^{-1}$. Limpahan bahang tanah selama penelitian cukup tinggi terutama menjelang akhir penelitian dimana tanah sudah semakin kering. Selama penelitian limpahan bahang tanah berkisar antara $4,7 \mathrm{~W} \mathrm{~m}^{-2}$ sampai $14,6 \mathrm{~W} \mathrm{~m}^{-2}$ dengan rata-rata $7,9 \mathrm{~W} \mathrm{~m}^{-2}$ sedangkan Nisbah Bowen berkisar antara 0,02 sampai 0,22 dengan rata-rata 0.10. Limpahan bahang laten berbanding lurus terhadap penerimaan radiasi neto yang mengenai kawasan persawahan dengan nilai berkisar antara $134,4 \mathrm{~W} \mathrm{~m}^{-2}$ sampai $226,5 \mathrm{~W}$ $\mathrm{m}^{-2}$ dengan rata-rata $184 \mathrm{~W} \mathrm{~m}^{-2}$.

\section{Pustaka}

Allen RG, Pereira LS, Raes D dan Smith M. 1998. Crop evapotranspiration guidelines for computing crop water requirements - FAO Irrigation and Drainage Paper, 56. Rome (US): FAO.
Gao Z, Bian L dan Zhou X. 2003: Measurements of turbulent transfer in the nearsurface layer over a rice paddy in China. J. Geophys. Res. 108: 4387, doi:10.1029/2002JD002779.

Grant DR. 1975. Comparisons of evaporation measurement using different methods. Quart. J. Roy. Meteorol. Soc. 101(429):543-550.doi:10.1002/qj .49710142911.

Jarvis PG, Stewart JB. 1979. Evaporation of water from pantation forest. In: E. D. Ford, D. C. Malcolm dan J. A. Herson (Eds). The ecology of evenage forest plantations [Internet]. Camridge (US): ITE. [diunduh 2012 April 14].

Rossenberg N, Blad B, Verma S. 1983. Microclimate: The Biological Environment. New Jersey (US): J Wiley.

Tsai J-L, Tsuang B-J, Lu P-S, Yao M-H dan Shen Y. 2007. surface energy components and land characteristics of a rice paddy. J. Appl. Meteor. Climatol. 46: 1879-1900.

Wang Y L, Wang X, Zheng Q Y, Li C H dan Guo X J. 2012. A comparative study on hourly real evapotranspiration and potential evapotranspiration during different vegetation growth stages in the zoige wetland. Procedia Environ. Sci. 13:1585-1594.doi:10.1016/j.proenv.2012.01.150. 